\title{
Frontal fibrosing alopecia and lichen planus pigmentosus: a case series
}

\author{
Diana Marcela Méndez; Claudia Marcela Arenas²; Camilo Andrés Morales³ \\ SUMMARY
}

Frontal fibrosing alopecia is a type of scarring alopecia that has been associated with different skin lesions including lichen planus pigmentosus. Both diseases share common pathophysiological mechanisms, which explain their coexistence in the same patient. We report 12 cases of mestizo women with frontal fibrosing alopecia and lichen planus pigmentosus confirmed by histopathology and discuss the pathophysiological mechanisms shared by both diseases. The most important pathophysiological mechanism common to both diseases is the cytotoxic T-lymphocyte response, which is directed against keratinocytes and hair follicle stem cells, causing apoptosis and damage to the basal layer, with consequent tissue remodeling that determines the clinical appearance of the lesions of frontal fibrosing alopecia and lichen planus pigmentosus.

KEY WORDS: Alopecia; Lichen planus; Facial papules; Physiopathology; Diagnosis.

\section{ALOPECIA FRONTAL FIBROSANTE Y LIQUEN PLANO PIGMENTOSO: SERIE DE CASOS}

\section{RESUMEN}

La alopecia frontal fibrosante es un tipo de alopecia cicatrizal que se ha asociado con diferentes lesiones cutáneas y con liquen plano pigmentoso. Existen mecanismos fisiopatológicos comunes a las dos enfermedades que explican su coexistencia en el mismo paciente. Se presentan los casos de 12 mujeres mestizas con alopecia frontal fibrosante y liquen plano pigmentoso confirmado por histopatología, y se discuten los mecanismos fisiopatológicos comunes a las dos enfermedades. El mecanismo fisiopatológico más importante que comparten las dos enfermedades es la respuesta inmunitaria mediada por linfocitos $\mathrm{T}$ citotóxicos, que se genera en contra de células como los queratinocitos y las células madre del folículo piloso, causa apoptosis y daño de la capa basal, con la consiguiente remodelación del tejido que determina la aparición de las lesiones clínicas de alopecia frontal fibrosante y liquen plano pigmentoso. La alopecia frontal fibrosante y el liquen plano pigmentoso son el espectro clínico de una misma enfermedad con manifestaciones clínicas variables.

PALABRAs CLAVE: : alopecia; liquen plano; pápulas faciales; fisiopatología; diagnóstico.

1. Dermatólogo, Hospital Universitario Centro Dermatológico Federico Lleras Acosta, E.S.E. Bogotá D.C., Colombia. ORCID https://orcid.org/oooo-0oo2-6834-1157

2. Dermatólogo, Hospital Universitario Centro Dermatológico Federico Lleras Acosta, E.S.E. Bogotá D.C., Colombia. ORCID https://orcid.org/oooo-ooo3-3689-5355

3. Dermatólogo, Hospital Universitario Centro Dermatológico Federico Lleras Acosta, E.S.E. Bogotá D.C., Colombia. Docente adjunto, Fundación Universitaria Sanitas, Bogotá, D.C., Colombia. ORCID https://orcid.org/00oo-0002-3187-3272

Correspondencia: Camilo Andrés Morales; email: camiderma@gmail.com

Recibido: 06/08/19; aceptado: 30/03/20

Cómo citar: Mendez DM, Arenas CM, Morales CA. Alopecia frontal fibrosante y liquen plano pigmentoso. Rev Asoc Colomb Dermatol. 2020;28(2): 176-183. DOI:

Financiación: ninguna, conflictos de interés: ninguno 


\section{INTRODUCTION}

Frontal fibrosing alopecia (FFA) is a type of primary lymphocytic scarring alopecia (1) that usually affects postmenopausal women (2) and is characterized by frontotemporal hairline recession, in addition to perifollicular erythema and follicular hyperkeratosis ${ }^{(3)}$. In most cases, there are other clinical manifestations, such as eyebrow and axillary alopecia (4). Recently, there have been reports of pigmented facial lesions associated with FFA, which were later diagnosed as lichen planus pigmentosus (LPP) ${ }^{(5-9)}$. LPP is an uncommon variety of lichen planus ${ }^{(10)}$, which manifests clinically as dark macules -greyish blue to brown color- ${ }^{(11)}$ with a diffuse, reticular, linear, or perifollicular pattern ${ }^{(12,13)}$, and present in exposed areas, mainly the face and neck $(9,10,12)$. Twelve cases of patients with FFA are reported, in which the association with LPP was confirmed by histopathology; the pathophysiological mechanisms that explain their coexistence are discussed.

\section{CASE DESCRIPTION}

This paper reports the cases of 12 mestizo women, with Fitzpatrick skin types III and IV, from the city of Bogota (Colombia), aged between 35 and 66 years (average 50 years), who consulted for the sudden appearance of asymptomatic, hyperpigmented macules on the face and neck (figure 1), of an average one-year duration, and no evident triggers or other associated diseases. Incidental physical examination findings included the symmetrical and bilateral recession of the frontotemporal hairline $(100 \%)$, partial or total alopecia of the eyebrows (100\%) (figure 2), and facial papules in the temporal region (66\%) (figure 3), which are typical clinical features of FFA (table 1). In all cases, skin biopsies of the pigmented facial lesions were taken, which revealed vacuolation of the basal layer, keratinocyte apoptosis, lymphocytic infiltration, and melanin incontinence (figure 4), which confirmed the diagnosis of LPP.
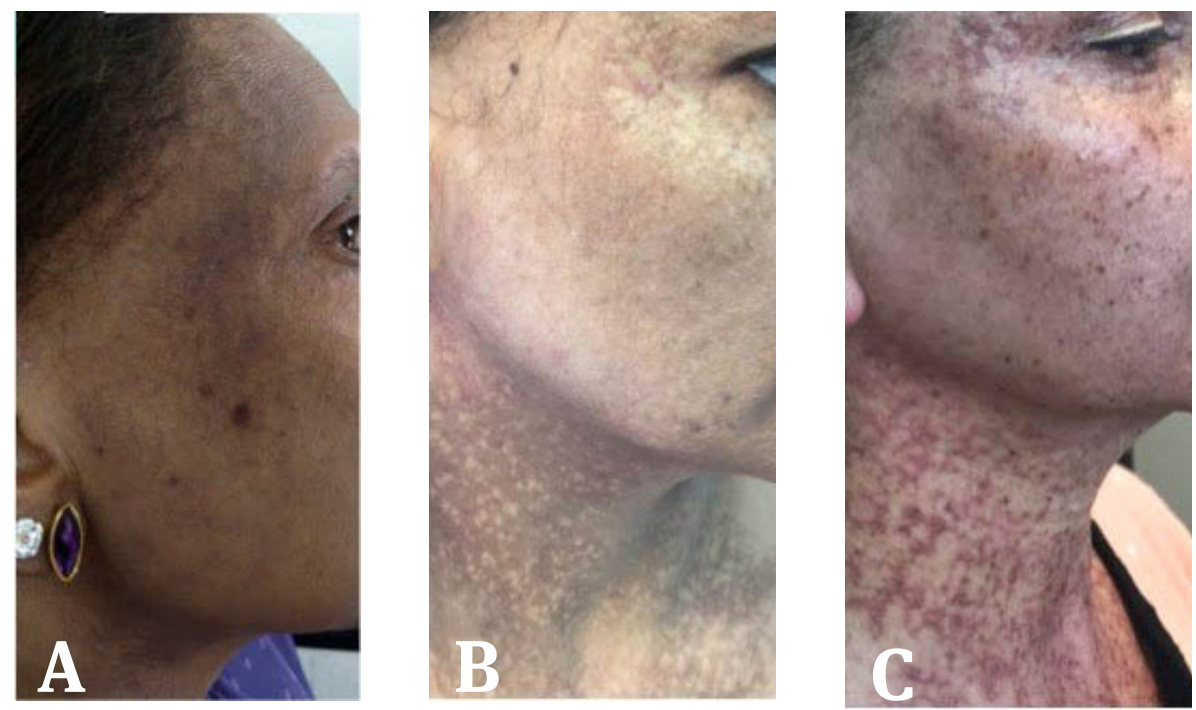

Figure 1. A-C) Clinical appearance of facial lesions: reticulate, diffuse macules, with colors that vary from slate grey to brownish black, are present on the face and neck. 

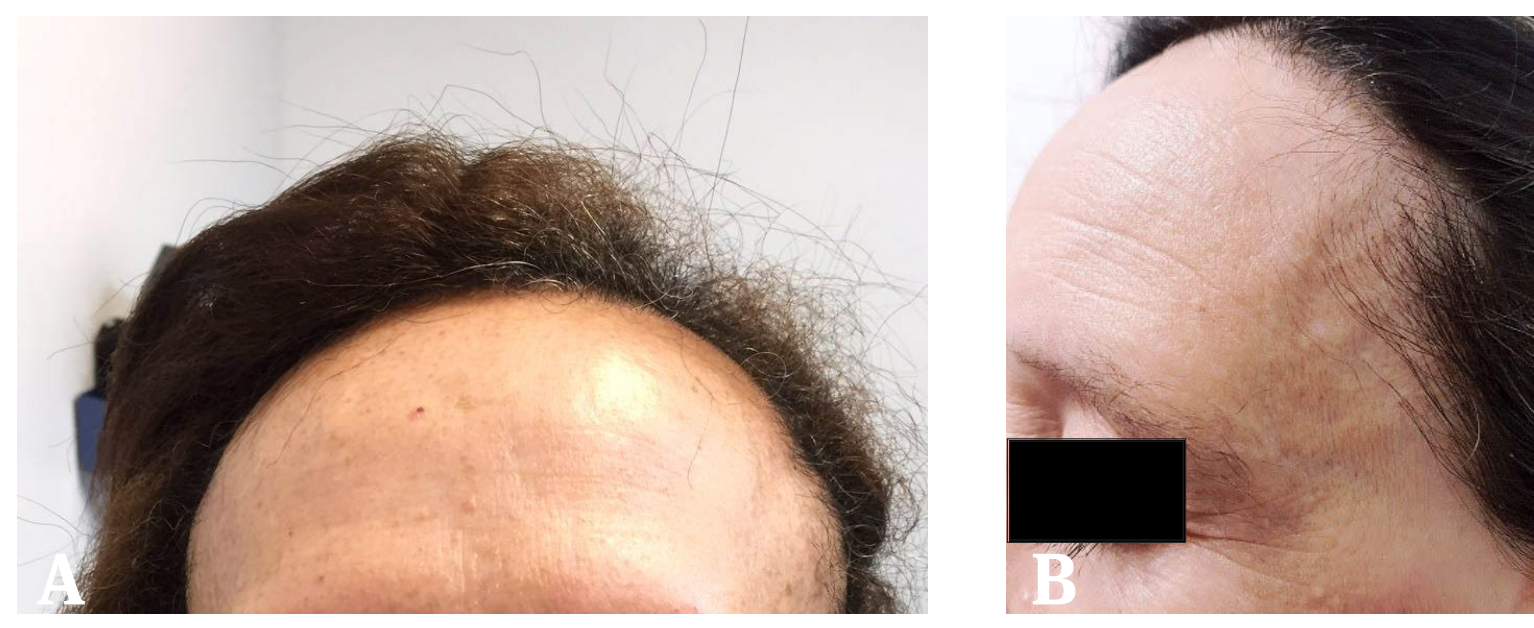

Figure 2. A-B) Clinical aspect of alopecia with symmetrical and bilateral, frontotemporal hairline recession associated with partial eyebrow loss and depressed temporal veins.
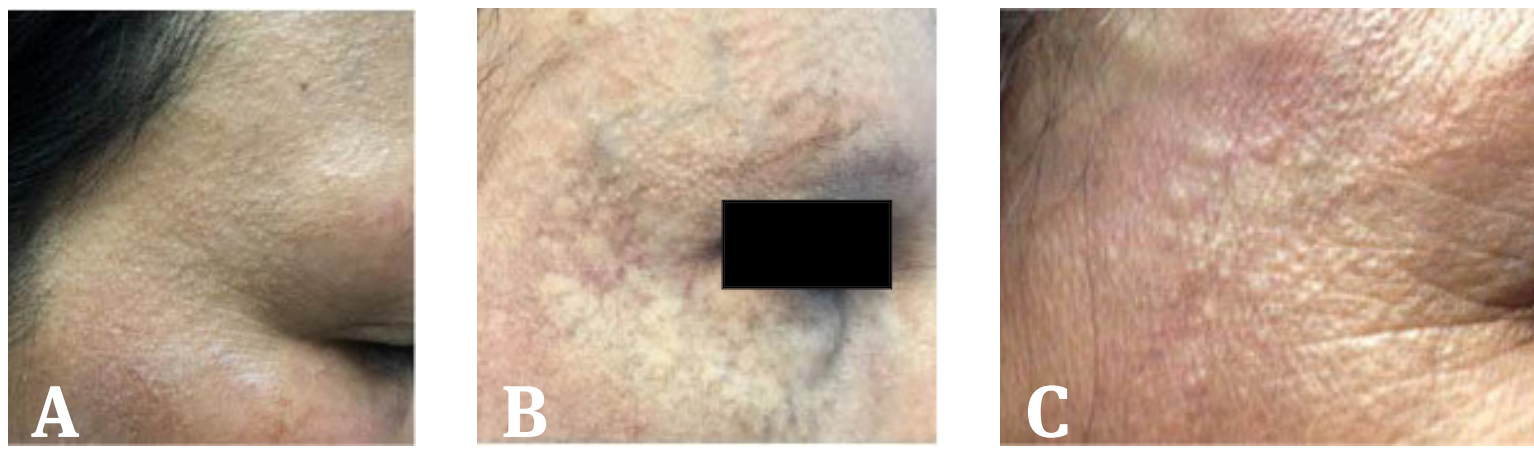

Figure 3. A-C) Facial papules represent the involvement of hair follicles in areas other than the scalp. Asymptomatic skin-colored papules are observed, which converge, giving a cobbled appearance. They are bilateral and are located more frequently in the temporal region and on the chin.

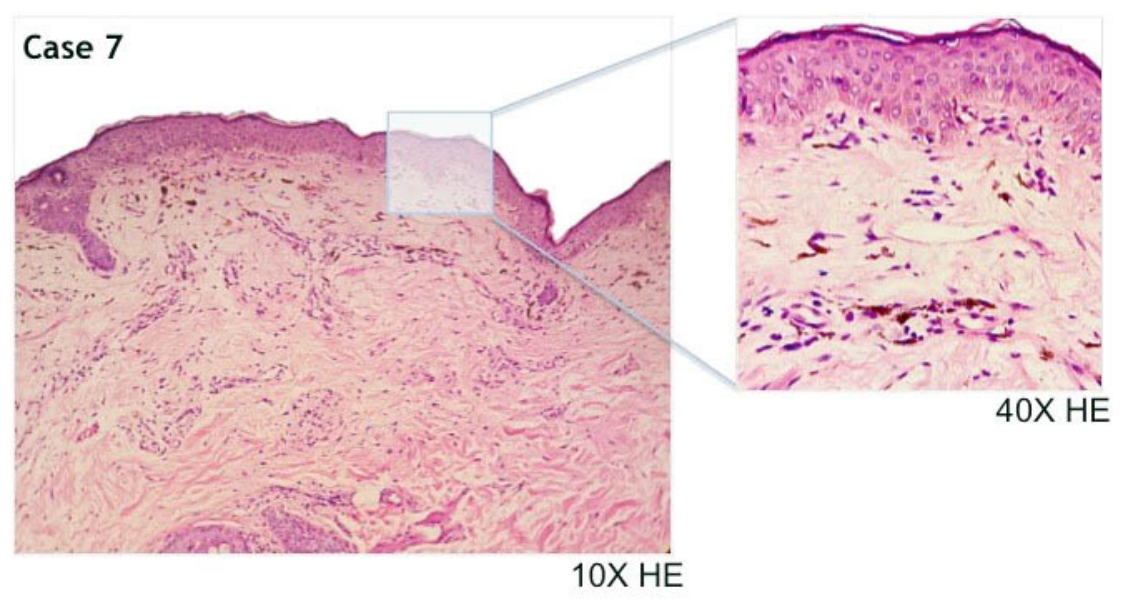

Figure 4. The images show an overview (10X) and detail (40X) of the skin biopsy stained with HE: Slight atrophy of the epidermis and vacuolar degeneration of the basal layer. A lymphohistiocytic infiltrate in the dermis can be observed, with melanophages and pigmentary incontinence. 
Table 1. Epidemiological characteristics and clinical manifestations of lichen planus pigmentosus in 12 women with frontal fibrosing alopecia.

\begin{tabular}{|c|c|c|c|c|c|c|c|}
\hline Case & Age & Phototype & Menopause & $\begin{array}{c}\text { LPP } \\
\text { duration } \\
\text { (months) }\end{array}$ & $\begin{array}{c}\text { Eyebrow } \\
\text { loss }\end{array}$ & $\begin{array}{c}\text { Facial } \\
\text { papules }\end{array}$ & $\begin{array}{c}\text { Pigmented } \\
\text { macules }\end{array}$ \\
\hline 1 & 35 & III & - & 18 & Partial & + & $\begin{array}{l}\text { Brownish } \\
\text { black }\end{array}$ \\
\hline 2 & 39 & IV & - & 12 & Total & + & Dark brown \\
\hline 3 & 57 & III & + & 3 & Total & - & Brown \\
\hline 4 & 50 & IV & - & 12 & Partial & + & Slate grey \\
\hline 5 & 51 & III & + & 24 & Total & + & Slate grey \\
\hline 6 & 53 & III & + & 5 & Total & + & Violaceous \\
\hline 7 & 60 & IV & + & 48 & Total & - & Slate grey \\
\hline 8 & 61 & IV & + & 8 & Total & + & Brown \\
\hline 9 & 38 & III & - & 10 & Total & + & Brown \\
\hline 10 & 40 & III & - & 84 & Partial & + & Slate grey \\
\hline 11 & 57 & IV & + & 24 & Total & - & Slate grey \\
\hline 12 & 66 & IV & + & 12 & Partial & - & Brown \\
\hline
\end{tabular}

+: present; -: absent; LPP: lichen planus pigmentosus.

\section{DISCUSSION}

FFA was described by Kossard in 1994 in postmenopausal patients ${ }^{(14)}$; however, after the original description, clinical cases have also been reported in men ${ }^{(2,}$ ${ }^{15)}$ and women of childbearing age ${ }^{(2,3,16-18)}$, as in this series, where $45 \%$ of the patients were premenopausal women, which allows considering different etiological factors than hormonal ones. One hundred percent of the women in this series had partial or total alopecia of the eyebrows, although the literature records an average frequency ranging from 50 to $83 \%{ }^{(19)}$.

The first facial lesions associated with frontal fibrosing alopecia were described in 2007 by Abbas et al.
${ }^{(17)}$ as facial papules corresponding to the involvement of facial hair follicles ${ }^{(17,20)}$. Later, there were reports of cases with follicular red dots in the glabella, frontal region, and cheeks ${ }^{(20,21)}$, and then LPP ${ }^{(5)}$. Facial papules were present in 66\% of these cases (figure 3), a higher prevalence in comparison with previous studies ${ }^{(8,18,20)}$ probably due to these patients' ethnicity, just as it has been described in other Hispanic/Latino population $^{(22)}$.

The presence of facial papules in patients with frontal fibrosing alopecia demonstrates that the clinical manifestations of the disease are not limited to the scalp and that these findings might be the first signs of the condition, allowing for an early diagnosis to be made 
(9). All patients had a clear idea of the duration of LPP, which was one year on average; however, the duration of FFA could not be established.

The coexistence of FFA and LPP was first described by Dlova in 2013 in a series of South African female patients ${ }^{(5)}$. Since then, other cases have been published, confirming this association ${ }^{(6-9)}$. In contrast to lichen planopilaris, which is associated to lichen planus lesions in up to $50 \%$ of cases ${ }^{(16)}$, only $5 \%$ of patients with FFA have lesions suggestive of lichen planus in other locations ${ }^{(23)}$. Therefore, this association could be related to intrinsic or extrinsic factors that have not yet been identified (figure 5). The etiology and pathophysiology of these two diseases are not completely known ${ }^{(19,24)}$; however, certain mechanisms present in both diseases have been described that explain this association (figure 6).

An early event in lesion development in FFA and LPP is keratinocyte antigen expression ${ }^{(25)}$, which is induced by external factors, such as drugs, contactants, and bacterial or viral infections, in people genetically predisposed to the condition or with hormonal changes $(1,26)$.

Antigens stimulate the release of keratinocyte cytokines, such as interferon gamma (IFNy) ${ }^{(27)}$, which produces chemotaxis and T-lymphocyte (TL) migration to the epidermis and hair follicle ${ }^{(19,24,28)}$. TL activation occurs after antigen binding to the major histocompatibility complex (MHC) class I in keratinocytes, which causes CD8-TL activation. Antigen binding to MHC class II in any antigen-presenting cell causes release of interleukin 12 (IL-12) with activation of CD4-TL; these CD4-TLs release more IL-12 and IFNy, promoting the activation of CD8-TL ${ }^{(26)}$ and explaining the severe cytotoxic responses in both diseases.

The mechanism of cell death in any type of lichen is apoptosis ${ }^{(25,29)}$, which occurs in different ways, including the release of cytokines, such as tumor necrosis factor alpha (TNFa), and the secretion of granzyme B by CD8-TL, which binds to receptors and enters the keratinocyte to induce its destruction or programmed cell death by the binding of the membrane protein Fas ligand (CD95L) - present on the TL surface- to its receptor in keratinocytes ${ }^{(26,27,30)}$. All of these factors activate the caspase pathway within the cell, which induces apoptosis ${ }^{(30)}$, ultimately causing damage to the basal layer ${ }^{(28)}$. Under normal conditions, the bulb and bulge of the hair follicle have a relative immune privilege, which serves as a protection strategy against autoimmune damage ${ }^{(29,31)}$. This protection is mediated by the negative regulation of MHC class I and II and beta-2-microglobulin, along with the production of immunosuppressants such as transforming growth factors (TGFs) $\beta 1$ and $\beta 2$, melanocyte-stimulating hormone $\alpha$, and glycoprotein CD200 ${ }^{(19,29)}$. In frontal fibrosing alopecia, a collapse of the immune privilege of the hair follicle mediated by IFNy occurs ${ }^{(19)}$; inflammatory cells infiltrate the bulge and destroy the epithelial stem cells, resulting in the loss of the regenerative potential of the hair follicle and permanent scarring alopecia ${ }^{(31,32)}$. It should be noted that other factors are also involved in the pathogenesis of frontal fibrosing alopecia, such as hormonal changes, PPARY deficiency, and trauma, among others ${ }^{(19,29)}$.
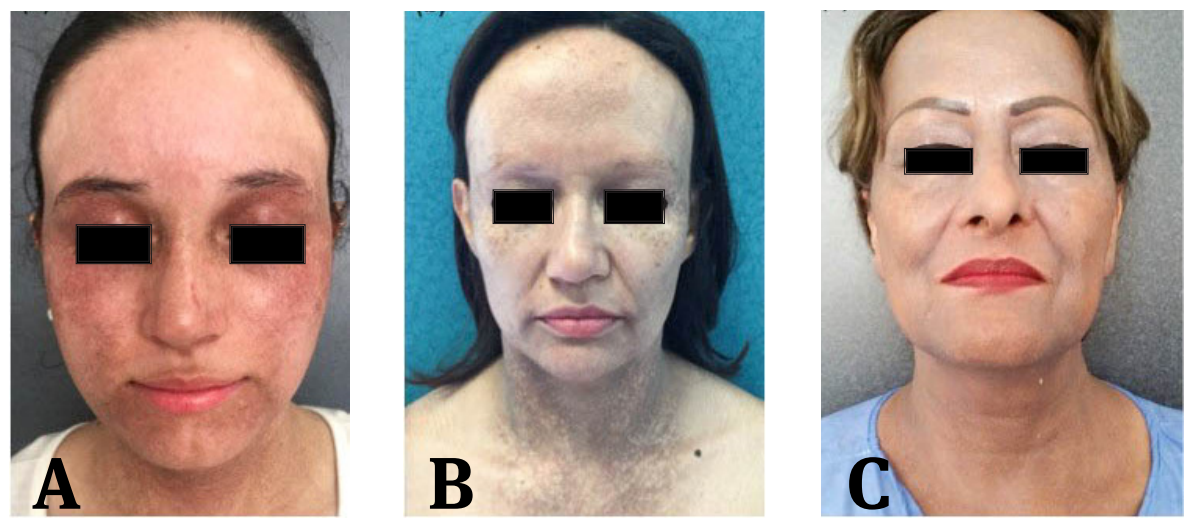

Figure 5. A-C) Clinical association of frontal fibrosing alopecia and lichen planus pigmentosus. 


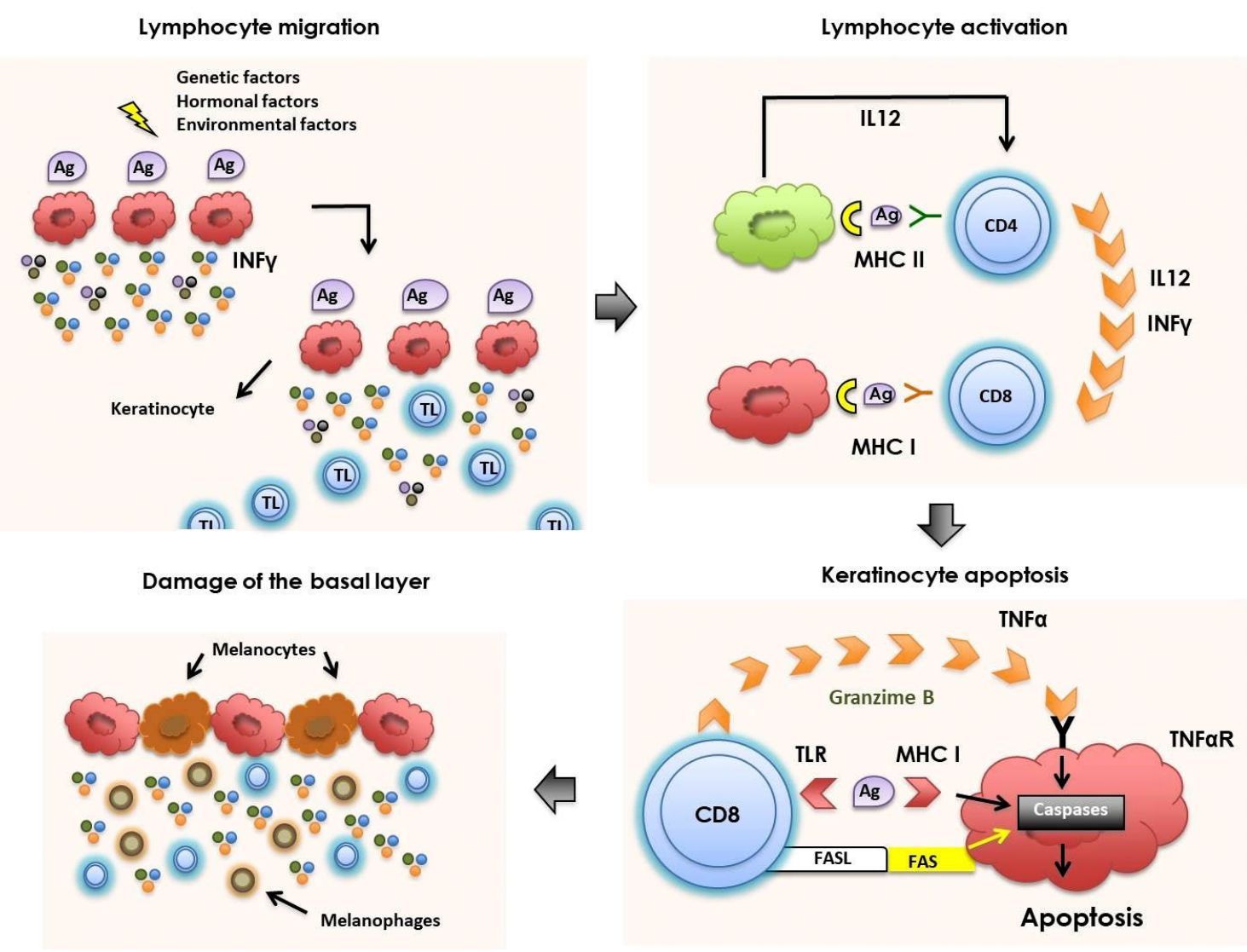

Figure 6. Immunological pathways common to frontal fibrosing alopecia and lichen planus pigmentosus. Keratinocyte antigen expression, induced by intrinsic and extrinsic factors, causes the release of various cytokines, such as interferon gamma (IFNY), which favors the migration of lymphocytes that are subsequently activated by binding to the major histocompatibility class complex I or II (MHC-I or MHC-II). In both diseases, the activation of CD8 T lymphocytes predominates (CD8-TL), with a severe cytotoxic response. CD8-TLs release various mediators of cell death that mediate keratinocyte apoptosis in the epidermis, the hair follicle, and the stem cells in the bulge, resulting in damage to the basal layer, which, in addition to other pathophysiological mechanisms, causes scarring alopecia and melanin incontinence.

In LPP, melanin incontinence occurs as a result of keratinocyte apoptosis and consequent damage to the basal layer ${ }^{\left({ }^{\circ}\right)}$. Melanin falls to the dermis and is phagocytosed by melanophages, causing skin pigmentation ${ }^{(24)}$. Therefore, the most important pathophysiological mechanism, common to both diseases, is the cytotoxic T cell immune response against cells such as keratinocytes and hair follicle stem cells, which leads to apoptosis and damage to the basal layer, with the consequent tissue remodeling responsible for the clinical lesions in both FFA and LPP ${ }^{(28)}$.

\section{CONCLUSION}

This case series supports the theory that FFA and LPP belong to the clinical spectrum of the same disease. Their diverse clinical manifestations depend on genetic, hormonal, and environmental factors that maintain and amplify the immune response, which explain the coexistence of both entities in the same patient. 


\section{Key Points}

- Twelve new cases of lichen planus pigmentosus in mestizo women with frontal fibrosing alopecia are reported.

- Facial papules were present in $66 \%$ of the cases, a higher prevalence in comparison with previous studies.

- Fibrosing alopecia is associated with different skin lesions, including lichen planus pigmentosus.

- The association between LPP and FFA can be explained by many common mechanisms present in both diseases.

- Cytotoxic T-lymphocyte response against keratinocytes and hair follicle stem cells causes apoptosis and damage to the basal layer.

\section{REFERENCES}

1. Olsen EA, Bergfeld WF, Cotsarelis G, Price VH, Shapiro J, Sinclair R, Solomon A, Sperling L, Stenn K, Whiting D, Bernardo O, Bettencourt M, et al. Summary of North American Hair Research Society (NAHRS) - Sponsored workshop on cicatricial alopecia, Duke University Medical Center, February 10 and 11, 2001. J Am Acad Dermatol. 2003;48(1):103-10. doi: $10.1067 / \mathrm{mjd} .2003 .68$

2. Chew A, Bashir S, Wain E, Fenton D, Stefanato C. Expanding the spectrum of frontal fibrosing alopecia: A unifying concept. J Am Acad Dermatol. 2010;63(4):653-60. doi: 10.1016/j.jaad.2009.09.020

3. Moreno-Ramírez D, Camacho F. Frontal fibrosing alopecia: a survey in 16 patients. J Eur Acad Dermatol Venereol. 2005;19(6):700-5. doi: 10.1111/j.1468-3083.2005.01291.X

4. Tosti A, Piraccini BM, Iorizzo M, Misciali C. Frontal fibrosing alopecia in postmenopausal women. J Am Acad Dermatol. 2005;52(1):55-60. doi: 10.1016/j.jaad.2004.05.014

5. Dlova NC. Frontal fibrosing alopecia and lichen planus pigmentosus: Is there a link? $\mathrm{Br} J$ Dermatol. 2013;168(2):439-42. doi: 10.1111/j.1365-2133.2012.11146.x
6. Berliner J, McCalmont T, Price V, Berger T. Frontal fibrosing alopecia and lichen planus pigmentosus. J Am Acad Dermatol. 2014;71(1):e26-7. doi: 10.1016/j.jaad.2013.12.031

7. Rao R, Sarda A, Khanna R, Balachandran C. Coexistence of frontal fibrosing alopecia with lichen planus pigmentosus. Int J Dermatol. 2014;53(5):622-4. doi: 10.1111/j.1365-4632.2012.05630.x

8. Pirmez R, Duque-Estrada B, Donati A, Campos-doCarmo G, Valente NS, Romiti R, Sodré CT, Tosti A. Clinical and dermoscopic features of lichen planus pigmentosus in 37 patients with frontal fibrosing alopecia. Br J Dermatol. 2016;175(6):1387-1390. doi: 10.1111/bjd.14722

9. Romiti R, Fátima C, Gavioli B, Anzai A, Munck A, Oliveira C, Valente NYS. Clinical and histopathological findings of frontal fibrosing alopecia-associated lichen planus pigmentosus. Skin Appendage Disord. 2017;3(2):59-63. doi: 10.1159/000456038

10. Buthani LK, Bedi TR, Pandhi RK, Nayak NC. Lichen planus pigmentosus. Dermatologica. 1974;149:43-50.

11. Gómez B, Salazar C, López S, Romano S, Lórenz M. [Lichen planus pigmentosus: a case report and literature review]. Arch Argent Dermatol. 2012;62:102-5. 
12. Kanwar AJ, Dogra S, Handa S, Parsad D, Radotra BD. A study of 124 Indian patients with lichen planus pigmentosus. Clin Exp Dermatol. 2003;28(5):481-5. doi: 10.1046/j.1365-2230.2003.01367.x

13. Sindhura KBN, Vinay K, Kumaran MS, Saikia UN, Parsad D. Lichen planus pigmentosus: A retrospective clinico-epidemiologic study with emphasis on the rare follicular variant. J Eur Acad Dermatol Venereol. 2016;30(11):e142-e144. doi: 10.1111/jdv.13454

14. Kossard S, Lee M, Wilkinson B. Postmenopausal frontal fibrosing alopecia: A frontal variant of lichen planopilaris. J Am Acad Dermatol. 1997;36(1):59-66. doi: 10.1016/s019o-9622(97)70326-8

15. Samrao A, Chew AL, Price V. Frontal fibrosing alopecia: A clinical review of 36 patients. Br J Dermatol. 2010;163(6):1296-300. doi: 10.1111/j.13652133.2010.09965.x

16. Faulkner C, Wilson N, Jones S. Frontal fibrosing alopecia associated with cutaneous lichen planus in a premenopausal woman. Australas J Dermatol. 2002;43(1):65-7. doi: 10.1046/j.1440-0960.2002.00558.x

17. Abbas O, Chedraoui A, Ghosn S. Frontal fibrosing alopecia presenting with components of Piccardi-Lassueur-Graham-Little syndrome. J Am Acad Dermatol. 2007;57(2 Suppl):15-8. doi: 10.1016/j.jaad.2006.11.010

18. Tan KT, Messenger AG. Frontal fibrosing alopecia: clinical presentations and prognosis. Br J Dermatol. 2009;16o(1):75-9. doi: 10.1111/j.1365-2133.2008.08861.X

19. Tziotzios C, Stefanato CM, Fenton DA, Simpson MA, McGrath JA. Frontal fibrosing alopecia: reflections and hypotheses on etiology and pathogenesis. Exp Dermatol. 2016;25(11):847-52. doi: 10.1111/exd.13071

20. López-Pestaña A, Tuneu A, Lobo C, Ormaechea N, Zubizarreta J, Vildosola S, Del Alcazar E. Facial lesions in frontal fibrosing alopecia (FFA): Clinicopathological features in a series of 12 cases. J Am Acad Dermatol. 2015;73(6):987.e1-e6. doi: 10.1016/j.jaad.2015.08.020

21. Pirmez R, Donati A, Valente NS, Sodre CT, Tosti A. Glabellar red dots in frontal fibrosing alopecia: A further clinical sign of vellus follicle involvement. Br J Dermatol. 2014;170(3):745-6. doi: 10.1111/bjd.12683

22. Mervis JS, Borda LJ, Miteva M. Facial and extrafacial lesions in an ethnically diverse series of 91 pa- tients with frontal fibrosing alopecia followed at a single center. Dermatology. 2019;235(2):112-9. doi: 10.1159/000494603

23. Moreno-Ramírez D, Ferrándiz L, Camacho FM. Diagnostic and therapeutic assessment of frontal fibrosing alopecia. Actas Dermosifiliogr. 2007;98(9):594-602. doi: 10.1016/S1578-219o(07)70524-3

24. Rieder E, Kaplan J, Kamino H, Sanchez M, Pomeranz MK. Lichen planus pigmentosus. Dermatol Online J. 2013;19(12):20713.

25. Gupta S, Jawanda MK. Oral lichen planus: an update on etiology, pathogenesis, clinical presentation, diagnosis and management. Indian J Dermatol. 2015;60(3):222-9. doi: 10.4103/0019-5154.156315

26. Roopashree MR, Gondhalekar RV, Shashikanth MC, George J, Thippeswamy SH, Shukla A. Pathogenesis of oral lichen planus -- a review. J Oral Pathol Med. 2010;39(10):729-34. doi: 10.1111/j.1600-0714.2010.00946.x

27. Di Lernia V. Targeting the IFN-c / CXCL1o pathway in lichen planus. Med Hipotheses. 2016;92:60-1.

28. Sontheimer RD. Lichenoid tissue reaction/interface dermatitis: clinical and histological perspectives. J Invest Dermatol. 2009;129(5):1088-99. doi: 10.1038/sj.jid.2009.42

29. Harries MJ, Paus R. The pathogenesis of primary cicatricial alopecias. Am J Pathol. 2010;177(5):2152-62. doi: 10.2353/ajpath.2010.100454

30. SehgalVN, SrivastavaG, SharmaS, SehgalS, Verma P. Lichenoid tissue reaction/interface dermatitis: clinicopathological overtones. Indian J Dermatology Venereol Leprol. 2011;77(4):418-29. doi: 10.4103/0378-6323.82389

31. Harries MJ, Meyer K, Chaudhry I, Kloepper JE, Poblet E, Griffiths CE, Paus R. Lichen planopilaris is characterized by immune privilege collapse of the hair follicle's epithelial stem cell niche. J Pathol. 2013;231(2):236-47. doi: 10.1002/path.4233

32. Rácz E, Gho C, Moorman PW, Noordhoek V, Neumann H. Treatment of frontal fibrosing alopecia and lichen planopilaris: A systematic review. J Eur Acad Dermatol Venereol. 2013;27(12):1461-70. doi: 10.1111/jdv.12139 